\title{
Iän virallinen muuttaminen tulisi sallia
}

\author{
Joona Räsänen
}

Kuvittele, että olet fyysisesti paremmassa kunnossa kuin muut ikäisesi. Olet heitä ketterämpi, nopeampi ja kestävämpi. Tunnet myös itsesi monin tavoin nuoremmaksi kuin virallisesti olet. Kuvittele, että kaikesta tästä huolimatta sinua syrjitään työmarkkinoilla ikäsi vuoksi. Et saa työpaikkaa, tai jos satut sellaisen saamaan, saatat tienata vähemmän kuin nuoremmat kollegasi ainoastaan siksi, että olet heitä vanhempi.

Tulisiko sinulla olla oikeus muuttaa virallista ikääsi vastaamaan kokemaasi ikää välttääksesi tämän syrjinnän?

Kysymys tuli ajankohtaiseksi, kun 69-vuotias hollantilaismies Emile Ratelband vaati oikeudelta lupaa muuttaa ikäänsä kaksikymmentä vuotta nuoremmaksi (hänen mukaansa tästä olisi hyötyä muun muassa internetin treffisivustoilla). Oikeus hylkäsi Ratelbandin vaatimukset, koska iän muuttaminen johtaisi sen mukaan monenlaisiin käytännön ongelmiin (BBC News 2018). Tästä huolimatta väitän, että on olemassa hyviä perusteita sille, että iän muuttaminen voitaisiin sallia - ainakin joissain tilanteissa (Räsänen 2019a).

Ratelbandin motiiveja voidaan arvostella ja voidaan kysyä, oliko hän tosissaan alun perinkään, mutta oletettavasti on ihmisiä, jotka aidosti haluaisivat muuttaa virallista ikäänsä. Tämän kirjoituksen taustalla on ajatus, että ikää muutettaisiin nuoremmaksi. En kuitenkaan periaatteesta vastusta sitäkään, että ikää muutettaisiin vanhemmaksi. Iän muuttaminen vanhemmaksi voisi kuitenkin johtaa erilaisiin käy- tännön ongelmiin kuin iän muuttaminen nuoremmaksi.

Näkemykseni mukaan iän muuttaminen tulisi sallia ainakin silloin, kun kaikki kolme seuraavaa ehtoa täyttyvät: Ensinnäkin on riski, että henkilö, joka haluaa muuttaa ikänsä, kohtaisi muuten syrjintää ikänsä vuoksi. Toiseksi hänen kehonsa ja mielensä ovat paremmassa kunnossa kuin voisi olettaa hänen kronologisen ikänsä (eli sen ajan, jonka hän on ollut olemassa) perusteella. Kolmanneksi henkilö itse ei koe, että hänen sen hetkinen virallinen ikänsä on hänelle oikea.

Iän virallinen muuttaminen voisi estää syrjintää, koska tällöin henkilön kronologinen ikä ei olisi esimerkiksi potentiaalisen työnantajan tiedossa eikä työnhakijaa voitaisi näin ollen sen perusteella syrjiä.

Ajatus iän virallisesta muuttamisesta saa usein samat vastaväitteet. Olen usein kuullut, että iän muuttaminen on mahdotonta, eikä sitä siksi voida sallia. Tämä vastaväite - jonka on esittänyt Saad (2019) - voidaan tulkita ainakin kahdella tapaa.

Ensimmäisen tulkinnan mukaan ikä viittaa aina kronologiseen ikään, siis siihen, kauanko olemme olleet elossa. Ikä on toisin sanoen vain ja ainoastaan mittari sille, kauanko jokin asia tai olio on ollut olemassa. Koska emme voi matkustaa ajassa taakse päin, emme myöskään voi muuttaa sitä, kauanko olemme olleet olemassa - siis ikäämme.

Toisen tulkinnan mukaan iän muutos tarkoittaisi käytännössä syntymäpäivän muutta- 
mista virallisiin dokumentteihin, kuten passeihin ja henkilökortteihin. Koska ihminen joko on tai ei ole syntynyt tiettynä päivänä, syntymäpäivän muuttaminen olisi virallisten dokumenttien vääristelyä, eikä sitä suinkaan voida sallia.

Aloitetaan ensimmäisestä vastaväitteestä. Se ei ole mielestäni kovin vakuuttava, sillä ikä ei aina tarkoita sitä, kauanko jokin on ollut olemassa. Aiemmin eräässä blogikirjoituksessani (Räsänen 2019c) käytin esimerkkinä viskiä: Viski ei tunnetusti vanhene pullossa. Viskin ikä tarkoittaa aikaa, joka on kulunut tislauksesta pullotukseen. 21-vuotias skottilainen single malt on edelleen 21-vuotiasta, vaikka juoma olisi ollut pullossa kaapin perällä pölyttymässä viimeiset kymmenen vuotta. Vaikka viski on siis ollut olemassa 31 vuotta, sanomme aivan oikein, että kyseinen viski on 21 vuotta vanhaa. Viskin kronologinen ikä ei ole merkityksellinen.

Kuvittele nyt, että olisi mahdollista syväjäädyttää eläviä ihmisiä erittäin alhaisessa lämpötilassa kymmeniksi vuosiksi. Kuvittele myös, että tämä teknologia hidastaisi ihmisten biologista vanhenemista vaikkapa kymmenesosaan nykyisestä tahdista. Henkilö, joka syväjäädytettäisiin 40-vuotiaana, heräisi sadan vuoden kuluttua ja olisi biologisesti yhtä hyvässä kunnossa kuin kuka tahansa 50 -vuotias. Et varmaan ajattele, että tätä henkilöä pitäisi kohdella lain edessä 140-vuotiaana, vaikka hän teknisessä mielessä olisikin ollut olemassa näin kauan? Luontevampaa olisi ajatella hänen olevan 50-vuotias. Jos et ole vakuuttunut, mieti samaa esimerkkiä lapselle. 8-vuotias, joka on syväjäädytettynä vuosia eikä vanhene biologisesti, on edelleen 8-vuotias eikä suinkaan saa avioitua, juoda alkoholia tai ajaa autoa sen jälkeen, kun hänet on herätetty.

Mutta ehkä se, mikä on soveliasta jäädytetyille ihmisille jokseenkin erikoisissa ajatuskokeissa, ei ole sopivaa oikeille ihmisille oikeassa elämässä. Kuitenkin edellä mainitun ajatuskokeen ja oikean elämän välillä on pääasiassa aste-ero, ei niinkään merkityksellistä laadullista eroa. Joku voisi toki väittää, että merkityksel- listä on se, onko ihminen ollut tajuissaan ja oikeasti elänyt elämäänsä; siis kokenut erilaisia asioita, joita elämän kulkuun yleensä liitämme. Koska syväjäädytettynä ihminen ei ole saanut uusia kokemuksia, ei hän ole myöskään vanhentunut - saattaa joku ajatella. Mutta elämän kokeminen ei ainakaan yksistään vaikuta merkitykselliseltä: emmehän yleensä ajattele, että esimerkiksi koomapotilaat sairaalan pedissä eivät vanhenisi, vaikka he eivät elämäänsä tajuttomana kokisikaan (Räsänen 2021).

Ihmiset vanhenevat biologisesti eri tahtiin (Ahadi ym. 2020). Se, kuinka nopeasti kehomme ja mielemme rappeutuvat ja kuinka nopeasti solumme tuhoutuvat, riippuu monista tekijöistä, kuten geeneistämme, epigeeneistämme ja elämäntavoistamme - esimerkiksi siitä, kuinka terveellisesti syömme (Sillanpää ym. 2019).

Biologinen ikä, joka viittaa ajan tuomiin muutoksiin ihmisen soluissa ja kudoksissa, on muun muassa gerontologiassa yleisesti käytössä oleva käsite siitä huolimatta, että ei ole täyttä yhteisymmärrystä siitä, kuinka biologinen ikä tulisi laskea. Usein biologista ikää arvioidaan erilaisilla mittareilla. Näitä ovat esimerkiksi käden puristusvoima tai keuhkojen hapenottokyky. Verinäytteistä voidaan tutkia solujen kromosomien päissä olevia jatkeita, telomeereja, ja niiden jakautumista. Ne kertovat henkilön biologisesta iästä. Jotkin biologisen iän laskutavat ennustavat esimerkiksi kuolleisuutta paremmin kuin kronologinen ikä (Chen \& Marioni 2016). Ihmiset, jotka ovat olleet olemassa yhtä kauan, voivat siis olla biologisesti eri ikäisiä, joten miksi heidän virallisten ikiensä tulisi olla samat?

Toisen vastaväitteen mukaan iän muuttaminen virallisesti edellyttäisi, että valtio hyväksyisi syntymäpäivän väärentämisen virallisiin dokumentteihin. Tätä ei joidenkin mielestä voida sallia.

Tämän vastaväitteen ongelman ymmärtämiseksi meidän on tunnistettava, että hyvin harvoin olemme kiinnostuneita ihmisen syntymäpäivästä sinänsä. Jos teini-ikäiseltä näyttävä ostaa alkoholia ja myyjä haluaa nähdä hänen 
henkilöllisyystodistuksensa, ei myyjä ole kiinnostunut ostajan syntymäpäivästä muista syistä kuin tietääkseen, onko tämä tarpeeksi vanha ostaakseen alkoholia. Syntymäpäivä ei ole itsessään juurikaan kiinnostava tieto (ellei sitten satu uskomaan horoskooppeihin). Kuten vastasin kriitikoilleni (Räsänen 2019b), syntymäpäivä on vain keino päästä käsiksi olennaiseen informaatioon eli siihen, kuinka vanha henkilö on.

Mitä jos henkilötodistuksemme olisivatkin vain sovelluksia älypuhelimissamme, ja ne näyttäisivät ikämme suoraan (30 vuotta) epäsuoran tavan sijaan (syntynyt 27. heinäkuuta 1990)? Jos kronologinen ikä - siis se, kauanko henkilö on ollut olemassa - ei ole merkityksellinen, kuten olen väittänyt, voisimme sallia sen, että"ikä" mobiilisovelluksessa viittaisi johonkin merkitykselliseen ikään (esimerkiksi biologiseen) kronologisen iän sijaan. Mitään tietoja ei silloin olisi vääristelty, sillä syntymäpäivää ei henkilötodistuksissa edes olisi, jolloin valehtelullekaan ei olisi sijaa."Ikä" virallisissa dokumenteissa tai sovelluksissa olisi itsestään päivittyvä luku, joka viittaisi johonkin, jolla on merkitystä (esimerkiksi arvioon biologisesta iästä).

Vastatessani kriitikoilleni (Räsänen 2019b) kysyin: jos iän muuttaminen sallittaisiin edellä kuvatussa kuvitteellisessa tilanteessa siitä syystä, että se ei olisikaan valehtelua iän näkyessä suoraan, miksi sitä ei sallittaisi myös oikeassa maailmassa, jossa ikä lasketaan syntymäpäivän perusteella passista tai ajokortista? Onko todella merkitystä sillä, ilmaisemmeko ikämme suoraan vuosina vai epäsuorasti päivämäärien kautta? Itse en ainakaan usko niin.

Ehkäpä iän muuttaminen johtaisi kuitenkin joihinkin hyvin outoihin lopputulemiin, eikä sitä siksi voitaisi sallia. Kuvitellaan vaikka, että 70-vuotias henkilö - olkoon hän esimerkiksi hollantilainen Emile - muuttaisi syntymäpäiväänsä 20 vuotta myöhemmäksi ja siten virallisen ikänsä 50-vuotiaaksi. Kuvitellaan myös, että Emile olisi saanut lapsen 18-vuotiaana. Jos 70-vuotiaasta Emilestä tulee 50-vuotias, hänestä tulisi virallisesti nuorempi kuin omasta lapsestaan, joka olisi 52-vuotias. Olisiko tämä hyvä peruste vastustaa iän muuttamista?

Vaikka edellä mainittu lopputulos on kieltämättä outo ja ennennäkemätön, ei se sinänsä ole riittävä syy olla sallimatta iän muuttamista. Se, että jokin on kummallista tai epätavallista, ei tarkoita, että se olisi väärin. Ehkäpä tulevaisuudessa se, että ihminen voi olla virallisesti omaa lastaan nuorempi, on yhtä normaalia kuin nykyisin on se, että samaa sukupuolta olevat voivat mennä keskenään avioon tai että henkilö, joka on lain mukaan mies, kykenee synnyttämään. Omituista? Kenties. Mutta kun ketään ei vahingoiteta, tuskin iän muuttamisen pitäisi olla kiellettyäkään?

Iän muuttaminen tulisi sallia, koska se voi vähentää ja estää ikään perustuvaa syrjintää esimerkiksi työmarkkinoilla eikä iän muuttaminen itsessään vahingoita ketään. Voi toki olla, että kronologisen, "oikean", iän selvittäminen kävisi joissakin tapauksissa käden käänteessä, vaikka virallista ikää olisikin muutettu, kuten Simkulet (2019) arvelee. Näin epäilemättä kävisi ainakin ensimmäisten iän muuttajien kohdalla jo pelkän asian tuoman julkisuuden takia - eikä iän muutos siten aina estäisi mahdollista syrjintää. Myös joissakin terveydenhuollon allokaatioon liittyvissä tapauksissa kronologisen iän käyttäminen tuntuu välttämättömältä. Näin on esimerkiksi elintärkeitä elimiä jaettaessa. On oikeudenmukaista jakaa elimet kronologisen iän perusteella ja suosia nuorempia, koska he ovat saaneet elää vähemmän aikaa (Lippert-Rasmussen \& Petersen 2020; Räsänen 2020). Mutta edellä mainitut ongelmat eivät tarkoita sitä, etteikö iän muuttamista joissain tilanteissa ja joillekin ihmisille voitaisi sallia.

Ikään perustuva syrjintä on valitettavasti todellinen ilmiö, joka on vahvasti linkittynyt yhteiskunnan rakenteisiin (Viitasalo 2011; 2015). Siksi tulisi keskittyä asenteiden ja ennakkoluulojen poistamiseen, jotta syrjintää saadaan kitkettyä. En ole kuitenkaan optimistinen, että pelkästään näillä keinoin syrjintä saadaan loppumaan. Iän virallinen muuttaminen voisi 
olla käytännöllinen ja toimiva ratkaisu joillekin heistä, jotka kohtaavat ikään perustuvaa syrjintää, vaikka se ei ikäsyrjinnän rakenteita todennäköisesti poistaisikaan.

Kuka uuden virallisen iän sitten määrittäisi ja saisiko ihminen valita iäkseen mielivaltaisesti mitä tahansa? Tuskin ihan mitä tahansa. Iän muuttaminen ei voisi olla vain henkilön ilmoitusasia, vaan hänen biologinen ikänsä tulisi jollain tavalla kyetä mittaamaan. Minulla ei ole vastauksia kaikkiin biologisen iän mittaamisen mahdollisiin ongelmiin. Nähdäkseni iän muuttamisen salliminen ja sen käytännön toteuttaminen vaatisikin useiden eri alojen asiantuntijoiden yhteistyötä. Joka tapauksessa, jos olen

\section{Kirjallisuus}

Ahadi S, Zhou W, Schüssler-Fiorenza Rose SM, Reza Sailani M, Contrepois K, Avina M ym. Personal aging markers and ageotypes revealed by deep longitudinal profiling. Nat Med 2020;26:83-90. https://doi.org/10.1038/s41591-019-0719-5

BBC News. Emile Ratelband, 69, told he cannot legally change his age. 2018. Internet: https://www. bbc.com/news/world-europe-46425774 (viitattu 4.12.2020).

Chen B, Marioni ME. DNA methylation-based measures of biological age: meta-analysis predicting time to death. Aging 2016;8(9):1844-65. https://doi.org/10.18632/aging.101020

Lippert-Rasmussen K, Petersen T. Age change, official age and fairness in health. J Med Ethics 2020;46(9):634-5. https://doi.org/10.1136/medethics-2020-106078

Räsänen J. Moral case for legal age change. J Med Ethics 2019a;45(7):461-464. https://doi.org/10.1136/medethics-2020-106144

Räsänen J. Further defence of legal age change: a reply to the critics. J Med Ethics 2019b;45(7):4712.

https://doi.org/10.1136/medethics-2019-105547

Räsänen J. Is changing legal age denying of facts? Blog, J Med Ethics, 2019c. Internet: https:// blogs.bmj.com/medical-ethics/2019/03/22/is- oikeassa, olen osoittanut - siinä määrin kuin filosofisella argumentoinnilla ylipäänsä voidaan mitään osoittaa - että on mahdollista antaa hyviä perusteluja sille, että iän muuttaminen tulisi jossain tilanteissa sallia.

Kirjoitus on lähdeviitelisäyksin ja pienin muutoksin suomennettu versio kirjoittajan englanninkielisestä kirjoituksesta Aeon-verkkolebdessä.

\section{Yhteydenotto:}

Joona Räsänen, filosofian väitöskirjatutkija, FM, VTM

Oslon yliopisto

joona.rasanen@ifikk.uio.no

changing-legal-age-denying-of-facts/ (viitattu 4.12.2020).

Räsänen J. Age change in healthcare settings: a reply to Lippert-Rasmussen and Petersen.J Med Ethics 2020;46(9):636-7.

https://doi.org/10.1136/medethics-2020-106144

Räsänen J. Age and ageing: what do they mean? Ratio 2021;34(1).

https://doi.org/10.1111/rati.12284

Saad T. Against the nihilism of 'legal age change': response to Räsänen.J Med Ethics 2019;45(7):465-6. https://doi.org/10.1136/medethics-2019-105475

Simkulet W. On legal age change. J Med Ethics 2019;45(7):469-70.

https://doi.org/10.1136/medethics-2019-105445

Sillanpää E, Ollikainen M, Kaprio J, Wang X, Leskinen T, Kujala UM. ym. Leisure-time physical activity and DNA methylation age - a twin study. Clin Epigenetics 2019;11:12. https://doi.org/10.1186/s13148-019-0613-5

Viitasalo N. Ikääntyvien kokema syrjintä työssä - Ikäsyrjinnän yleisyys ja ennustajat. Työelämän tutkimus 2011;9(3):256-71.

Viitasalo N. Varttuneet ja ikäsyrjintä työelämässä. Acta Universitatis Tamperensis 2114. Tampereen yliopisto, 2015. 